\title{
Ruthenium-Catalyzed Dehydrative Benzofuran Synthesis via C-H Activation
}

Gategory

Synthesis of

Heterocycles

Key words

benzofurans

C-H activation

ruthenium catalysis<smiles>Oc1ccccc1</smiles><smiles>[AlH2]</smiles>
(1 equiv) 2 (1.2 equiv)

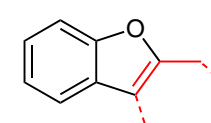

4<smiles>C1=CCc2c(oc3c2ccc2ccccc23)C1</smiles>

$4190 \%$
24 examples $43-94 \%$ yield

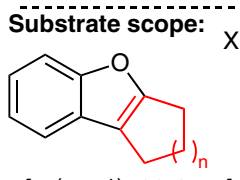

$4 a(n=1) 66 \%$

$\mathbf{4 b}(\mathrm{n}=2) \quad 86 \%$
$\mathbf{4 c}(\mathrm{n}=3)$

4d $(n=1, X=O M e) \quad 89 \% \quad$ 4h (R = Et) $83 \%$

$4 \mathrm{e}(\mathrm{n}=1, \mathrm{X}=\mathrm{F}) \quad 71 \% \quad 4 \mathrm{i} \quad(\mathrm{R}=n-\mathrm{Bu}) 85 \%$

$4 f(n=2, X=O M e) 91 \%$ 4j $(R=P h) \quad 90 \%$

$\mathbf{4 g}(n=3, X=$ OMe $) 94 \%$<smiles></smiles>

4n $84 \%$<smiles></smiles>

$4087 \%$<smiles>CCCCc1cc2c(OC)cc(OC)cc2o1</smiles>

$4 p 89 \%$<smiles>CC1(C)COc2c(ccc3ccccc23)C1</smiles>

$4 \mathrm{~m} 43 \%$<smiles>CCOC(=O)C(N)Cc1ccc2oc3c(c2c1)CC[15C](=[18O])Cc1ccccc1-3</smiles><smiles>COc1ccc2c3c(oc2c1)C1C(C(=O)c2ccccc2)C3C(C(=O)N2C(=O)c3ccccc3C2=O)C1C(C)(C)C</smiles>

4u $63 \%$

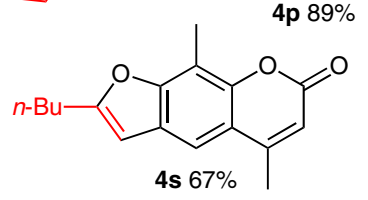
4s $67 \%$<smiles></smiles>
4v $81 \%$<smiles>Cc1coc2c(C(C)C)c3c(cc12)[C@@]1(C)CCCC(C)(C)C1CC3</smiles>

4 w $82 \%$
Significance: Reported is the ruthenium-catalyzed dehydrative ortho-functionalization of phenols $\mathbf{1}$ with diols 2 affording benzofurans $\mathbf{4}$. When simple alcohols were employed, only ortho-functionalized phenols were obtained (not shown). When diols 2 were employed, the cyclized benzofurans $\mathbf{4}$ were the preferred products. Inclusion of an excess of a simple alkene (cyclopentene) promoted the coupling reaction. An impressive array of substrates were shown to undergo the transformation (4a-x), including more complex diols $(\mathbf{4 u} \mathbf{u})$ and structurally elaborate phenols $(\mathbf{4 s}, \mathbf{4 v}, \mathbf{4} \mathbf{w})$. A cursory investigation of the reaction mechanism is also reported.
Comment: The present report represents a highly convenient and robust method for the synthesis of substituted benzofurans, which are medicinally relevant heterocycles with a diverse range of biological activities (see Review below). The sheer scope and high yields of the reported process appear to make this method highly attractive for the synthesis of 2-substituted benzofurans. It would be interesting to know if the process performed as well on scale (10 $\mathrm{g}$ and above) as it does on more standard quantities ( $1 \mathrm{mmol})$.

Review: L. De Luca, G. Nieddu, A. Porcheddu, G. Giacomelli Curr. Med. Chem. 2009, 16, 1-20.

SYNFACTS Contributors: Victor Snieckus, Matthew O. Kitching

Dol: 10.1055/s-0032-1316516; Reg-No.: V06012SF 